\title{
EARLY DECREASE IN SECRETIN-, GLUCAGON-, AND ISOPROTERENOL-STIMULATED CARDIAC ADENYLATE CYCLASE ACTIVITY IN RATS TREATED WITH ISOPROTERENOL
}

\author{
Pierre Chatelain*, Patrick Robberecht, Philippe De Neef, Jean-Cl.aude Camus \\ and JEAN CHRISTOPHE \\ Department of Biochemistry and Nutrition, Medical School, Université Libre de Bruxelles, Bld, de \\ Waterloo 115, B-1000 Brussels, Belgium, and "Continental Pharma Research Laboratories, \\ B-1830 Machelen, Belgium
}

(Received 12 February 1981; accepted 30 July 1981)

\begin{abstract}
Male Wistar albino rats received three times daily for one to five days 0.25 to $5.0 \mathrm{mg} / \mathrm{kg}$ $\mathrm{D}, \mathrm{L}$-isoproterenol intraperitoneally. D,L-Isoproterenol injections provoked a time dependent- and dose-related cardiac hypertrophy. With moderate hypertrophy, a selective decrease in secretin-stimulated adenylate cyclase activity occurred. When heart hypertrophy was more pronounced, greater losses in secretin-, as well as in D,L-isoproterenol-, glucagon-, guanine nucleotide-, and fluoride-stimulated enzyme activity developed. Hormone stimulations of adenylate cyclase were more severely curtailed ( 60 to $65 \%$ ) than guanine nucleotide or fluoride stimulations ( 40 to $45 \%$ ). The accompanying loss in $\beta$-receptors $(35 \%)$ was proportionately lower than the loss of D,L-isoproterenol sensitivity of adenylate cyclase. This complex partern of adenylate cyclase desensitization in heart membranes from animals chronically treated with $\mathrm{D}, \mathrm{L}$-isoproterenol is reminiscent of that observed in heart membranes from spontaneously hypertensive rats.
\end{abstract}

The cardiac adenylate cyclase of rats is a several hormone-sensitive system that can be stimulated by isoproterenol, secretin-VIP,† and glucagon. We observed recently [1-3] that this activity is altered in spontaneously hypertensive (SHR) rats: the hormone sensitivity of the enzyme is impaired whereas the basal as well as the guanine nucleotide- and fluoride-stimulated activities are unaffected. When the hypertension is established, the pattern of adenylate cyclase alterations includes decreased secretinVIP $(80 \%)$, glucagon, and isoproterenol ( 40 to $50 \%$ ) efficacies. These alterations develop early in the course of the disease, are not corrected by an efficient antihypertensive treatment [4], and are not reproduced by renovascular hypertension in Goldblatt rats [1]. The cardiac hypertrophy that appears in SHR rats before the onset of hypertension is indeed considered as reflecting an hyperactivity of adrenergic fibers and triggering the hypertension $[5,6]$.

In the present work we attempted (1) to reproduce in normotensive rats the pattern of cardiac adenylate cyclase activity observed in SHR rats; (2) to further evaluate the relationship between various classes of hormonal receptors in heart membranes during in vivo administration of one type of hormonal stimulus.

† Abbreviations used: $\mathrm{Gpp}[\mathrm{NH}] \mathrm{p}$, guanosine $5^{\prime}-\mathrm{O}-(2$ 3-imido)-triphosphate; SHR, Okamoto spontaneously hypertensive rat; LH, luteinizing hormone; VIP, vasoactive intestinal peptide; b.wt, body weight.
To achieve our aim we treated normotensive rats for 1 to 5 days with increasing concentrations of the $\beta$-adrenergic agonist D,L-isoproterenol and the resulting cardiac hypertrophy was correlated with adenylate cyclase activity in cardiac membranes.

\section{MATERIALS AND METHODS}

Animal treatment. Male albino Wistar rats weighing between 250 and $280 \mathrm{~g}$ and bred in our laboratory were fed ad libitum until the time of sacrifice. Groups of 6 rats that were distributed at random were injected intraperitoneally, 3 times daily (at 8.00 a.m., 1.00 p.m., and 6.00 p.m.), for 1 to 5 days, with $\mathrm{D}, \mathrm{L}$-isoproterenol freshly dissolved in $0.15 \mathrm{M} \mathrm{NaCl}$. The volume injected was about $0.2 \mathrm{ml}$ and the concentration of isoproterenol was adjusted so as to inject each time 0.25 to $5.0 \mathrm{mg}$ of the drug, per $\mathrm{kg}$ body weight. Control animals received equivalent volumes of $0.15 \mathrm{M} \mathrm{NaCl}$ vehicle. The animals were killed by decapitation in the morning $(8.00 \mathrm{a} . \mathrm{m}$.) $14 \mathrm{hr}$ following the last injection (at $6.00 \mathrm{p} . \mathrm{m}$.). The hearts were excised, dissected out quickly, rinsed with $0.15 \mathrm{M} \mathrm{NaCl}$, dried on a filter paper, weighed, and frozen individually in liquid nitrogen.

Cardiac membrane preparation. The cardiac tissue was defrosted, disrupted with an Ultra-Turrax for $10 \mathrm{sec}$, and further homogenized with a glass-Teflon homogenizer at $2^{\circ}(5 \% \mathrm{w} / \mathrm{v}$ homogenate) in $20 \mathrm{mM}$ Tris- $\mathrm{HCl}$ buffer enriched with $2 \mathrm{mM}$ dithioerythritol and $5 \mathrm{mM} \mathrm{MgCl}$ ( $\mathrm{pH} 7.5)$. After filtration through two layers of medical gauze, the homogenate was centrifuged at $520 \mathrm{~g}$ for $10 \mathrm{~min}$. The pellet was 
resuspended at $2^{\circ}$ in $20 \mathrm{mM}$ Tris- $\mathrm{HCl}, 5 \mathrm{mM} \mathrm{MgCl}$. $0.25 \mathrm{M}$ sucrose ( $\mathrm{pH} 7.5$ ). An equal volume of the same buffer enriched with $2.5 \mathrm{M} \mathrm{KCl}$ was added dropwise. The suspension was stirred continuously for $1 \mathrm{hr}$ at $2^{\circ}$ and centrifuged at $37,000 \mathrm{~g}$ for $10 \mathrm{~min}$. The pellet was resuspended in a $10 \mathrm{mM}$ Tris- $\mathrm{HCl}$. $2 \mathrm{mM}$ dithioerythritol, $0.25 \mathrm{mM}$ sucrose ( $\mathrm{pH} 7.5$ ), washed three times in this buffer and finally resuspended in a volume of buffer allowing a final protein concentration of approximately $6 \mathrm{mg} / \mathrm{ml}$, as determined by the Lowry et al. procedure [7], using bovine serum albumin as a standard.

Adenylate cyclase assay. Adenylate cyclase activity was determined with minor modifications of the Salomon et al. procedure [8]. Cardiac membranes (approx. $60 \mu \mathrm{g}$ protein) were incubated in a total volume of $60 \mu \mathrm{l}$ containing $0.5 \mathrm{mM}\left[\alpha-{ }^{12} \mathrm{P}\right]$-ATP, $5 \mathrm{mM} \mathrm{MgCl}, 0.5 \mathrm{mM}$ EGTA, $1 \mathrm{mM}$ cyclic AMP, $1 \mathrm{mM}$ theophylline, $10 \mathrm{mM}$ phospho(enol)pyruvate, $30 \mu \mathrm{g} / \mathrm{ml}$ pyruvate kinase and $30 \mathrm{mM}$ Tris $-\mathrm{HCl}$ and a final $\mathrm{pH}$ of 7.5. When the effects of D,L-isoproterenol, glucagon or secretin were tested, $10^{-5} \mathrm{M}$ GTP was added to the medium.

The reaction was initiated by addition of mem. branes and was terminated after $8 \mathrm{~min}$ at $37^{\circ}$ by adding $0.5 \mathrm{ml}$ of a $0.5 \%$ sodium dodecylsulfate solution containing $0.5 \mathrm{mM}$ ATP, $0.3 \mathrm{mM}$ cyclic AMP and 20,000 counts $\mathrm{min}^{-1}$ of cyclic $\left[8-^{-3} \mathrm{H}\right]$-AMP (for determination of cyclic nucleotide recovery). Cyclic AMP was separated from ATP by two successive chromatographies on Dowex $50 \mathrm{~W} \times 8$ and neutral alumina. The kinetics of adenylate cyclase activity were linear under all conditions tested, including in the presence of $\mathrm{Gpp}[\mathrm{NH}] \mathrm{p}$.

Membrane $\beta$-receptor assay. $\beta$-Adrenergic receptors in cardiac membranes were evaluated by incubating for $60 \mathrm{~min}$ at $25^{\circ}, 90$ to $110 \mu \mathrm{g}$ membrane protein with $0.2 \mathrm{nM}\left[{ }^{125} \mathrm{I}\right]$ hydroxybenzylpindolol and increasing concentrations of unlabeled pindolol in $120 \mu \mathrm{l}$ of $20 \mathrm{mM}$ Tris-maleate enriched with $5 \mathrm{mM}$ $\mathrm{MgCl}_{2}, 1 \mathrm{mM}$ dithioerythritol, $0.1 \mathrm{mg} / \mathrm{ml}$ bacitracin. $0.1 \mathrm{mg} / \mathrm{ml}$ ascorbic acid, and $1 \%$ bovine serum albumin ( $\mathrm{pH} 7,0$ ). Membrane-bound radioactivity was separated from free radioactivity by filtration through glass fiber filters GF/C (Whatman, Maidstone, U.K.) and washed three times with ice-cold buffer. Specific binding was defined as total binding minus the binding in the presence of $1 \mu \mathrm{M}$ pindolol.

Chemicals. Cyclic $\left[8{ }^{3} \mathrm{H}\right]-\mathrm{AMP}$ and $\left[\alpha^{3}{ }^{3} \mathrm{P}\right]-\mathrm{ATP}$, obtained from the Radiochemical Centre (Amersham, U.K.), had a specific radioactivity of,

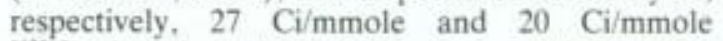
[25] hydroxybenzylpindolol had a specific radioactivity of $2200 \mathrm{Ci} / \mathrm{mmole}$ and was obtained from NEN (Munich, F.R.G.). Synthetic secretin was a generous gift from Dr. W. König (Hoechst Aktiengesellschaft, Frankfurt, F.R.G.), porcine glucagon was a gift from Novo Industries (Ets. Couvreur, Brussels, Belgium). Phospho(enol)pyruvate, pyruvate kinase, cyclic AMP, D, L-isoproterenol, ATP (sodium salt, grade 1) and bovine serum albumin were purchased from Sigma Chemical Co. (St. Louis, MO, U.S.A.). GTP and $\mathrm{Gpp}[\mathrm{NH}] \mathrm{p}$ were from Boehringer (Mannheim. F.R.G.). All other reagents were of the highest grade available.

Statistical evaluation of the data. Comparison of the results was performed using the Student's $t$ test on non-paired values.

\section{RESULTS}

In a first series of experiments D,L-isoproterenol was injected 3 times daily for 5 days at a low $(0.5$ $\mathrm{mg} / \mathrm{kg} \mathrm{b}$,wt) or high ( $5 \mathrm{mg} / \mathrm{kg} \mathrm{b}$,wt) dose. The body weight was unaffected. By contrast, cardiac hypertrophy was already significant after a one day treatment at the low dose $(+10 \%)$ and became more severe subsequently ( $+50 \%$ after 5 days at the highest D,L-isoproterenol dose) (Fig. 1).

The basal as well as the GTP, Gpp[NH]p-, D,Lisoproterenol-, glucagon-, and secretin-stimulated adenylate cyclase activities were evaluated in cardiac membranes. Results obtained with maximal concentrations of stimuli are expressed in Figs, 2 and 3 as percentage of the corresponding values in cardiac membranes from control rats. This representation was justified since there were no significant variations between the data obtained in different control groups. The absolute values of basal and $1.10^{-5} \mathrm{M}$ GTP-stimulated adenylate cyclase activities were unaffected by the treatment, as indicated in the legend of figures. After a 1 day treatment at the low $\mathrm{D}, \mathrm{L}$-isoproterenol dose the only significant alteration was a 20 per cent decrease in secretin efficacy. After 5 days, $\mathrm{NaF}$ - and $\mathrm{Gpp}[\mathrm{NH}]$ p-stimulated cardiac adenylate cyclase activities decreased moderately (by 10 and $25 \%$, respectively) and secretin and D, L-isoproterenol sensitivities were more severely affected (by $45 \%$ and $35 \%$, respectively).

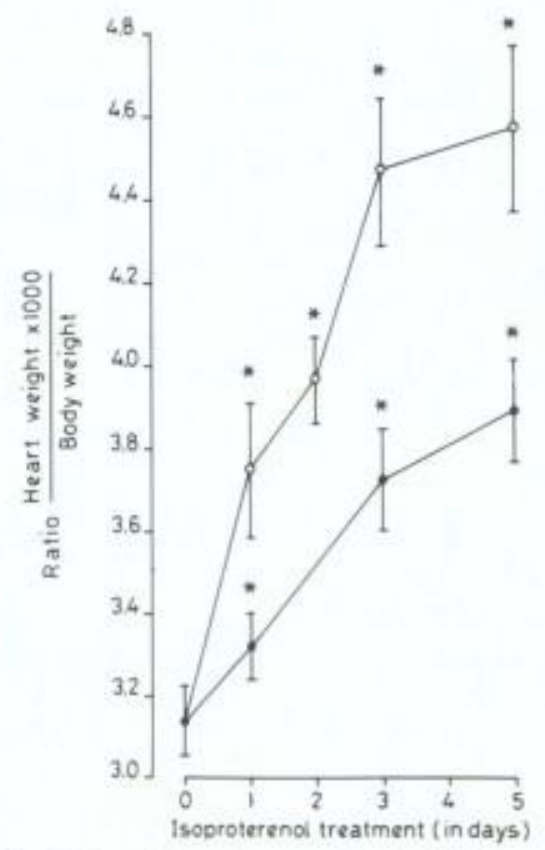

Fig. 1. Effects of D,L-isoproterenol administered 3 times daily for 5 days at the dose of $0.5 \mathrm{mg} / \mathrm{kg} \mathrm{b}$.wt (-) and $5 \mathrm{mg} / \mathrm{kg}$ b.wt $(\mathrm{O}-\mathrm{O})$ on heart hypertrophy evaluated with the heart to body weight ratio. Results were the means \pm S.E.M. from 6 animals. Values in treated rats significantly higher $(\mathrm{P}<0.05)$ than in control rats receiving $0.15 \mathrm{M} \mathrm{NaCl}$. 


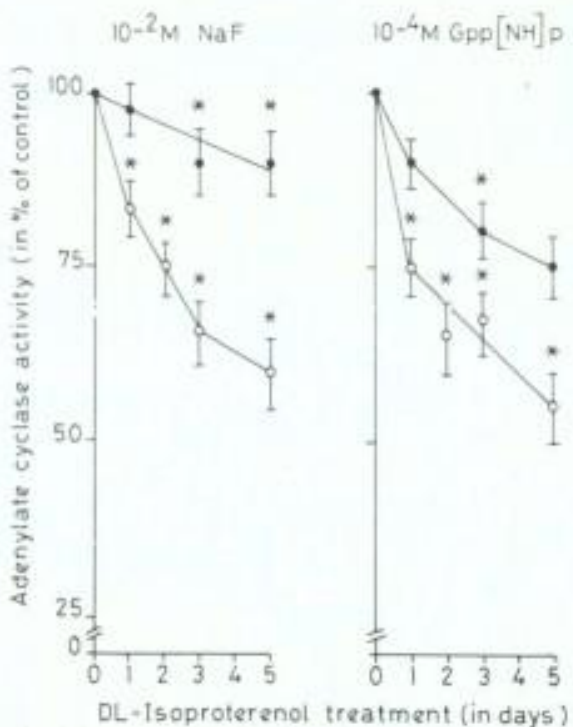

Fig. 2. Time study of the effects of D,L-isoproterenol administered 3 times daily at the dose of $0.5 \mathrm{mg} / \mathrm{kg} \mathrm{b}$.wt (-) and $5 \mathrm{mg} / \mathrm{kg} \mathrm{b}$.wt $\left(\mathrm{O}-\mathrm{O}\right.$ ) on $10^{-2} \mathrm{M} \mathrm{NaF}$ (left panel) and $10^{-4} \mathrm{M}$ Gpp $[\mathrm{NH}] \mathrm{p}$ (right panel) stimulated adenylate cyclase activities. Results are the means \pm S.E.M. from 6 animals and were expressed in $\%$ of the values in cardiac membranes from control rats receiving $0.15 \mathrm{M} \mathrm{NaCl}$. - Values significantly lower $(\mathrm{P}<0.05)$ than in control membranes. The mean absolute values of basal adenylate cyclase activity and of $10 \mathrm{mM} \mathrm{NaF}$ and $1 \cdot 10^{-5}$ $\mathrm{M} \mathrm{Gpp}[\mathrm{NH}] \mathrm{p}$ stimulated activities in control animals of rats receiving the high $\mathrm{D}, 1$-isoproterenol dose were, respectively, $34 \pm 4,358 \pm 15$, and $115 \pm 7$ pmoles cyclic

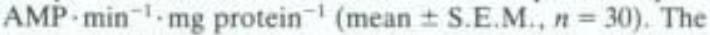
corresponding values in control animals of rats treated with the low D,L-isoproterenol dose were, respectively, $32 \pm 2$, $339 \pm 17, \quad 118 \pm 8$ pmoles cyclic AMP $\min ^{-1} \cdot \mathrm{mg}$ protein $^{-1}$ (mean \pm S.E.M., $n=24$ ). There were no significant variations in the absolute values obtained in different control groups.

When administering D,L-isoproterenol at high dose, the reduction in adenylate cyclase activity was more rapid and more pronounced, especially when tested under stimulation of hormone receptors. Furthermore, after 1 day, the 55 per cent decrease in secretin efficacy was more severe than the 30 and 25 per cent decreases in, respectively, D, L-isoproterenol and glucagon efficacies. After five days treatment, the fluoride and $\mathrm{Gpp}[\mathrm{NH}] \mathrm{p}$-stimulated adenylate cyclase activities dropped by $40-45$ per cent whilst the various hormonal-stimulated enzyme activities were reduced by as much as $60-65$ per cent.

In a second series of experiments, the effects of increasing doses of $\mathrm{D}, \mathrm{L}$-isoproterenol administered for 3 days were evaluated. As shown in Fig. 4, there was a dose-related increase in the heart to body weight ratio. The lowest $\mathrm{D}, \mathrm{L}$-isoproterenol dose tested $(0.25 \mathrm{mg} / \mathrm{kg}$ b.wt 3 times daily) provoked already a significant cardiac hypertrophy. Here again, there were no significant variations in adenylate cyclase activity in cardiac membranes from different control groups and the absolute values of basal and $1 \cdot 10^{-5} \mathrm{M}$ GTP-stimulated adenylate cyclase activities were unaffected by the treatment (see legend of Figs 5 and 6). The efficacies of Gpp[NH]p, $\mathrm{NaF}, \mathrm{D}, \mathrm{L}$-isoproterenol, secretin, and glucagon on cardiac adenylate cyclase activity are illustrated in Figs 5 and 6. A dose-related decrease in adenylate cyclase activity was observed with all stimuli tested, the hormone stimulations being more affected than $\mathrm{Gpp}[\mathrm{NH}] \mathrm{p}$ and fluoride stimulations. The secretin sensitivity was already reduced by D,L-isoproterenol injections at $0.25 \mathrm{mg} / \mathrm{kg} \mathrm{b}$. wt that were without effect on the response to the $\beta$-adrenergic agonist. The glucagon response was moderately enhanced at the lowest dose of D,L-isoproterenol but decreased definitely when concentrations higher than $1 \mathrm{mg} / \mathrm{kg} \mathrm{b}$.wt were administered 3 times daily.

In a third series of experiments, the dose-effect relationship of five stimuli on adenylate cyclase activity were compared on cardiac membranes from control rats and rats treated 3 times daily for 3 days with $\mathrm{D}, \mathrm{L}$-isoproterenol at $5 \mathrm{mg} / \mathrm{kg}$ b.wt. The major effect of the treatment was a decline in the efficacy of $\mathrm{D}, \mathrm{L}$-isoproterenol, glucagon and secretin, with no significant modification in the concentration of each stimulant producing half-maximal stimulation (Fig. 7). Similar data were obtained with $\mathrm{Gpp}[\mathrm{NH}] \mathrm{p}$ - and fluoride-stimulated activities (not shown). In treated animals, the number and affinity of $\beta$-receptors was evaluated with the binding of the labeled antagonist $\left.{ }^{125} \mathrm{I}\right]$ hydroxybenzylpindolol to cardiac membranes. Competition curves performed in the presence of increasing concentrations of unlabeled pindolol and D,L-isoproterenol demonstrated that the apparent affinity of $\beta$-receptors was identical in control and treated animals so that tracer binding in the absence of added unlabeled ligand allowed a direct estimation of the number of $\beta$-receptors. This number was reduced by the treatment to $65 \pm 5$ per cent (mean \pm S.E.M., $n=5$ ) of the value found in cardiac membranes from control animals.

\section{Discussion}

Cardiac hypertrophy was induced in rats shortly after initiating a chronic $\mathrm{D}, \mathrm{L}$-isoproterenol treatment and further increased with time (Fig. 1). Previous studies have shown that the initial increase in cardiac weight is due to edema $[9,10]$ but this is followed by an accumulation of protein, RNA and DNA. Zimmer and Ibel [11] have also reported that a single injection of $25 \mathrm{mg} / \mathrm{kg}$ b.wt isoproterenol increases cardiac protein synthesis. Large infarcts are associated with massive doses of D, L-isoproterenol (20-80 $\mathrm{mg} / \mathrm{kg}$ b.wt) [12]. No gross cardiac anomalies were observed in the present study. It is possible that minimal hypoxic lesions were present in the heart of rats injected three times daily with 4 and $5 \mathrm{mg} / \mathrm{kg}$ b.wt D,L-isoproterenol [13] but even so, it is unlikely that they were responsible for the present results since myocardial ischemia produces an increase in the number of $\beta$-receptors [14] rather than the decrease reported here.

After the in vivo administration of $\mathrm{D}, \mathrm{L}$-isoproterenol, a sequential alteration in cardiac adenylate cyclase activity developed, limited at first to a decrease in secretin efficacy, then impairing progressively the efficacy of D,L-isoproterenol, and 


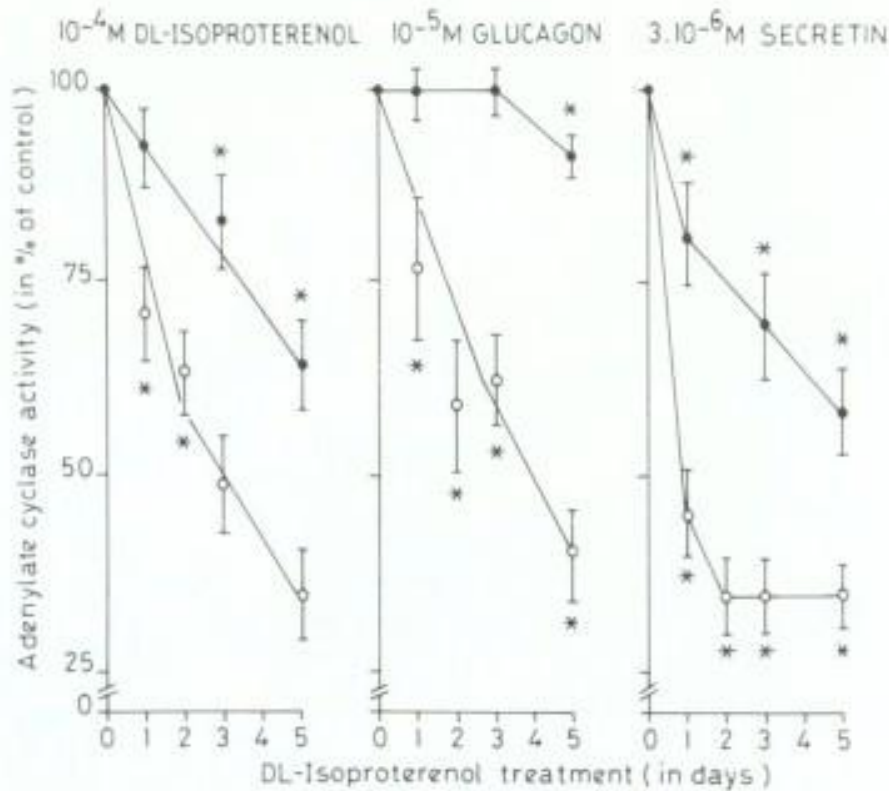

Fig. 3. Same experimental protocol and symbols as in Fig. 2. The left, middle and right panels represent, respectively, the relative values observed with $10^{-4} \mathrm{M} \mathrm{D}, \mathrm{L}$-isoproterenol, $10^{-5} \mathrm{M}$ glucagon and $3 \cdot 10^{-6}$ $\mathrm{M}$ secretin-stimulated adenylate cyclase activities. The stimulated adenylate cyclase activity was calculated after subtraction of the unstimulated value observed in the presence of $10^{-5} \mathrm{M}$ GTP. The mean absolute values of $10^{-5} \mathrm{M}$ GTP, $10^{-4} \mathrm{M}$ D,L-isoproterenol, $10^{-5} \mathrm{M}$ glucagon, and $3 \cdot 10^{-6} \mathrm{M}$ secretin stimulated adenylate cyclase activities in control animals of rats receiving the high $\mathrm{D}, \mathrm{L}$-isoproterenol dose were, respectively, $38 \pm 2,166 \pm 7,98 \pm 6$, and $102 \pm 7$ pmoles cyclic AMP' min $^{-1}$ ' mg protein $^{-1}$ (mean \pm S.E.M., $n=30$ ). The corresponding values in control animals of rats treated with the low D,L-isoproterenol dose were, respectively, $35 \pm 3,170 \pm 8,100 \pm 6$, and $102 \pm 8$ pmoles cyclic AMP $\cdot \min ^{-1} \cdot \mathrm{mg}$ protein ${ }^{-1}$ (mean \pm S.E.M., $n=24$ ). There were no significant variations in the absolute values obtained in different control groups.

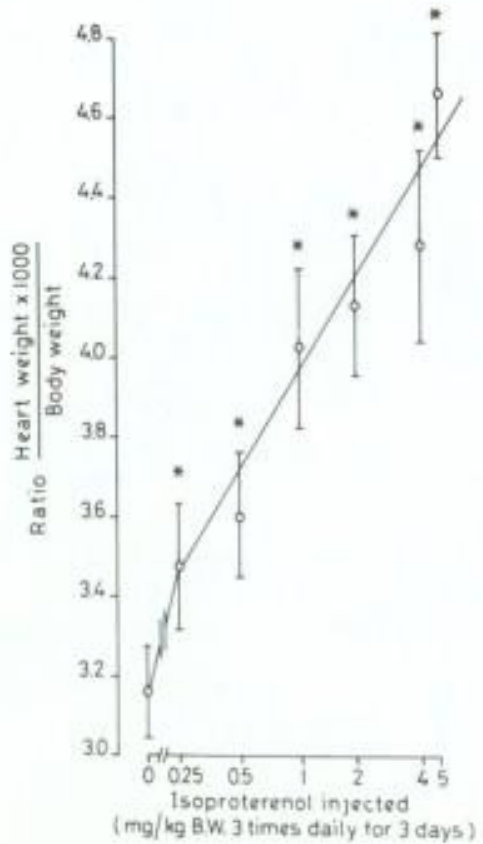

Fig. 4. Effects of D.L-isoproterenol administered 3 times daily for 3 days at concentrations ranging from $0.25 \mathrm{mg} / \mathrm{kg}$ b.wt to $5 \mathrm{mg} / \mathrm{kg} \mathrm{b}$, wt on heart hypertrophy evaluated with the heart to body weight ratio. Results were the means \pm S.E.M. from 6 animals. "Values in treated rats significantly higher $(\mathrm{P}<0.05)$ than in control rats receiving $0.15 \mathrm{M} \mathrm{NaCl}$.

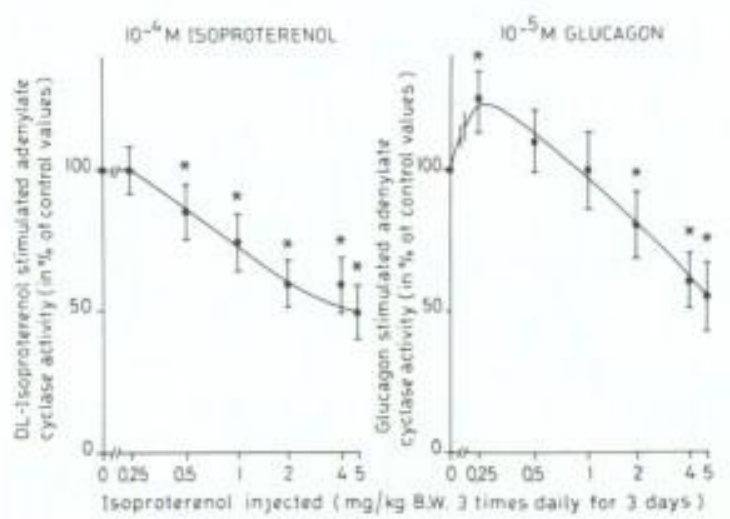

Fig. 5. Effects of D,L-isoproterenol administered 3 times daily for 3 days at concentrations ranging from $0.25 \mathrm{mg} / \mathrm{kg}$ b.wt to $5 \mathrm{mg} / \mathrm{kg}$ b.wt on cardiac adenylate cyclase activity stimulated with $10^{-4} \mathrm{M}$ D,L-isoproterenol (left panel) or $10^{-5} \mathrm{M}$ glucagon (right panel). Results are the means \pm S.E.M. from 6 animals and were expressed in $\%$ of the values in cardiac membranes from control rats receiving $0.15 \mathrm{M}$ saline. ${ }^{*}$ Values significantly different $(\mathrm{P}<0.05)$ from those in control rats. The stimulated adenylate cyclase activity was calculated after subtraction of the unstimulated value observed in the presence of $10^{-5} \mathrm{M}$ GTP. The mean absolute value of $10^{-3} \mathrm{M}$ GTP, $10^{-4} \mathrm{M}$ D,L-isoproterenol and $10^{-5} \mathrm{M}$ glucagon stimulated adenylate cyclase activities in control rats were, respectively, $40 \pm 4,180 \pm 10$, and $120 \pm 12$ pmoles cyclic AMP $\cdot$ min $^{-1} \cdot$ mg protein $^{-1}$ (mean \pm S.E.M., $n=6$ ). 


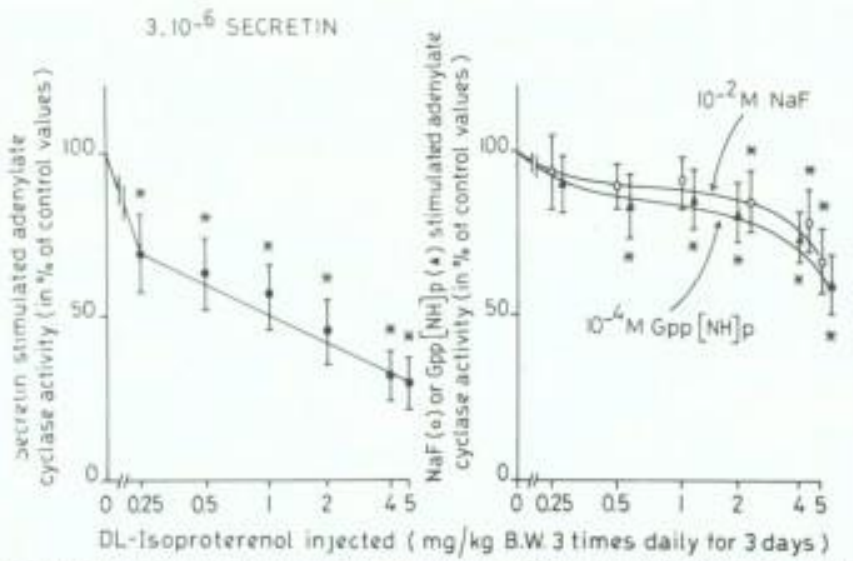

Fig. 6. Same experimental protocol and symbols as in Figs, 4 and 5. The left and right panels represent. respectively, the adenylate cyclase activity in $\%$ of control values stimulated with $3 \cdot 10^{-6} \mathrm{M}$ secretin (-) and $10^{-2} \mathrm{M} \mathrm{NaF}(\mathrm{O}-\mathrm{O})$ or $10^{-4} \mathrm{M} \mathrm{Gpp}[\mathrm{NH}] \mathrm{p}(\mathbf{\Lambda}-\mathbf{A})$. The mean absolute value of basal, $3 \cdot 10^{-6} \mathrm{M}$ secretin, $10 \mathrm{mM} \mathrm{NaF}$ and $10^{-4} \mathrm{M} \mathrm{Gpp}(\mathrm{NH}) \mathrm{p}$ stimulated adenylate cyclase activities in control rats were, respectively, $35 \pm 3,115 \pm 5,362 \pm 25$, and $125 \pm 9$ pmoles cyclic AMP. min $^{-1} \cdot \mathrm{mg}^{\circ}$ protein $^{-1}($ mean \pm S.E.M., $n=6)$.

finally that of glucagon, Gpp[NH]p, and fluoride. The efficacy of agents acting on receptors at the outer face of cardiac membrane was, in general, more severely affected than that of Gpp[NH]p and $\mathrm{NaF}$ acting on guanine nucleotide binding site(s) and the catalytical unit, at the inner face of membranes (Figs. 2 and 3).

A number of mechanisms that are not self-exclusive probably contributed to the described complex pattern of altered cardiac adenylate cyclase activity. These might conceivably include the uncoupling of the adenylate cyclase system from hormonal receptors, followed by the homologous or heterologous down-regulation of hormone receptor-mediated adenylate cyclase activity, the internalization of hormonal receptors and/or of the entire adenylate cyclase system, and selective reductions in the rates of receptor synthesis.

Recent experiments have shown that hormone or prostaglandin exposure can result in various affinity states of the receptors, in the uncoupling of the adenylate cyclase system from hormonal receptors, and in general refractoriness [15]. As an example. plasma membranes of turkey erythrocytes incubated with isoproterenol present decreased responsiveness to isoproterenol, Gpp[NH]p, and fluoride, with no change in the number of $\beta$-receptors [16]. This fully reversible phenomenon is observed relatively shortly after hormone exposure [17]. A similar alteration could be partly responsible for the early modification in adenylate cyclase activity that we observed in cardiac membranes (Figs. 2 and 3).

After 5 days of treatment, the apparent affinity of D, L-isoproterenol, secretin and glucagon for the adenylate cyclase system, remained unaffected despite decreased efficacy (Fig. 7), which suggests that in heart membranes adenylate cyclase stimulation was a direct function of receptor occupancy, due to the lack of 'spareness' of these receptors. This further loss of adenylate cyclase activity that developed after one day reflected an in vivo down-regulation of particular interest since the response to secretin, after D, L-isoproterenol administration, was affected earlier than the response to D,L-isoproterenol itself.

Recent experiments have shown that a first administration of a given agonist may decrease the response of adenylate cyclase to a second administration of the same agonist (homologous down-regulation: ref. 18) or to another stimulant (heterologous down-regulation: refs 19,20 ). The molecular basis of these phenomena is uncertain but is often attributed to receptor loss. The loss of $\beta$-adrenergic receptors, the heterologous desensitization, and the reduction in Gpp[NH]p-, and fluoride-stimulated adenylate cyclase activities could also be explained by the internalization of hormone receptors and/or of the entire adenylate cyclase system. This phenomenon has been described for insulin [21], epidermal

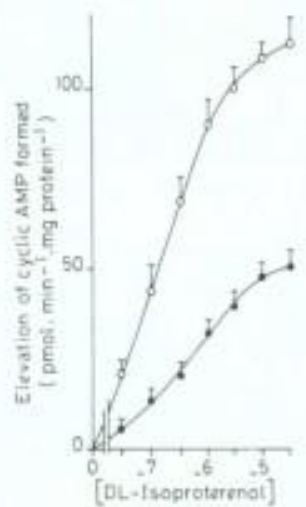

( $\log M$ )

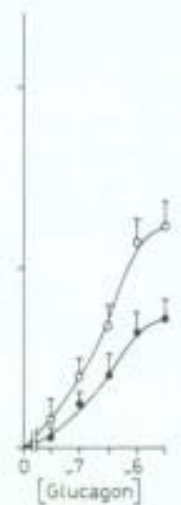

$(\log M)$

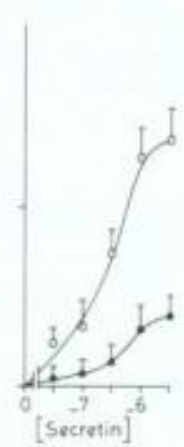

$(\log M)$
Fig. 7. Dose-effect relationship of D,L-isoproterenol (left panel), glucagon (middle panel), and secretin (right panel) on adenylate cyclase activation of heart membranes prepared from control rats $(\mathrm{O}-\mathrm{O})$ or rats treated 3 times daily for 3 days with $5 \mathrm{mg} / \mathrm{kg}$ b.wt D,L-isoproterenol. Results are the means \pm S.E.M. from 6 animals. The mean value of the unstimulated activity observed in the presence of $10^{-5} \mathrm{M}$ GTP that was subtracted from the stimulated values was, respectively, $38 \pm 6$ and $35 \pm 8$ pmoles cyclic

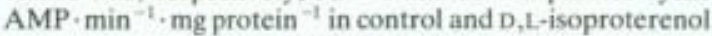
treated animak. 
growth factor [22], and $\alpha_{2}$ macroglobulin receptors $[23,24]$ : the occupied receptors are clustered in coated pits in plasma membranes before being internalized $[24,25]$. A last contributor to desensitization was probably caused by the lack of synchronism in the turnover of membrane components. The increased cardiac protein synthesis observed after administration of isoproterenol [11] is of necessity accompanied by the synthesis of new membrane components that together must cope with the observed hyperplasia and hypertrophy of cells. The present experiments suggest that the rates of turnover of hormone receptors and of the constituents of the adenylate cyclase system were not regulated in parallel. Selective alterations in rates of new membrane protein synthesis have also been described during the down- and up-regulation of growth hormone receptors in cultured lymphocytes [26].

Whatever the basic mechanism(s) involved in the control of receptor-mediated adenylate cyclase activation in cardiac membranes, two functional consequences can be considered, one with pharmacological and another one with physiopathological bearing: Firstly, the decreased number of $\beta$-adrenoreceptors and the reduced D, L-isoproterenol-stimulated adenylate cyclase activity observed in D,L-isoproterenolinduced cardiac hypertrophy can be correlated with the decreased contractile force of ventricular muscle preparations following prolonged exposure to a $\beta$ adrenergic agonist [13]. It would be of interest to examine whether the physiological response to cardioactive peptides was also impaired following the same treatment. Secondly, the pattern of cardiac adenylate cyclase activity observed after administration of low doses of D, L-isoproterenol, including a marked alteration in secretin efficacy, a moderate decrease in D,L-isoproterenol efficacy, and little alteration in glucagon, Gpp[NH]p- and fluoridestimulated enzyme activity was similar to that observed in membranes from the hypertrophied heart of spontaneously hypertensive (SHR) rats (see Introduction). These analogies support the concept that hyperactivity of cardiac adrenergic nerves may be important in the initiation of cardiac hypertrophy in SHR rats and that such an excessive adrenergic stimulation leads to multiple impairment of the adenylate cyclase system [1-3].

Acknowledgements-Aided by Grant 20,403 from the Fonds de la Recherche Scientifique Médicale (Belgium), Grant RO-IAM-17010 from the National Institutes of Health (U.S.A.), Grant 3317 from I.R.S.I.A. (Belgium), and a Grant from the Ministère de la Politique Scientifique (Belgium).

\section{RE.FERENCES}

1. P. Chatelain, P. Robberecht, P. De Neef, M. Claeys and J. Christophe, FEBS Lett, 107, 86 (1979).

2. P. Chatelain, P. Robberecht, P. De Neef, J. C. Camus, D. Heuse and J. Christophe, Pflügers Arch. 389, 29 (1980).

3. P. Robberecht, J. Winand, P. Chatelain, P. Poloczek. J. C. Camus, P. De Neef and J. Christophe, Biochem. Pharmac. 30, 385 (1981).

4. P. Chatelain, M. Waelbroeck, J. C. Camus, P. De Neef, P. Robberecht, J. Roba and J. Christophe, Eur. J. Pharmac. 72, 17 (1981).

5. L. Weiss and Y. Lundgren, Cardiovasc. Res, 12, 635 (1978).

6. A. F. Cutilletta, L. Erinoff, A. Heller, J. Low and S. Oparil, Circulat. Res, 40, 428 (1977).

7. O. H. Lowry, N. J. Rosebrough, A. L. Farr and R. J. Randall, J. biol. Chem. 193, 265 (1951).

8. Y. Salomon, C. Londos and M. Rodbell, Analyt. Biochem. 58, 541 (1974).

9. M. C. Stanton, G. Brenner and E. D. Mayfield, Am. Heart 77, 72 (1969).

10. J. Tse, N. L. Brackett and J. F, Kuo, Biochim. biophys. Acta 542, 399 (1978).

11. H. G. Zimmer and H. Ibel, FEBS Lett, 106, 335 (1979).

12. G. Rona, C. I. Chappel, T. Balazs and R. Gaudry, Arch. Pathol. 67, 443 (1959).

13. J. Tse, J. R. Powell, C. A. Baste, R. E. Priest and J. F. Kuo, Endocrinology 105, 246 (1979).

14. A. Mukherjee, T. M. Wong, L. M. Buja, R. J. Lefkowitz and J. T. Willerson, J. Clin. Invest. 64, 1423 (1979).

15. K. J. Catt, J. P. Harwood, G. Aguilera and M. L. Dufau, Nature, Lond. 280, 109 (1979).

16. B. B. Hoffman, D. Mullikin-Kilpatrick and R. J. Lefkowitz, J. Cyclic Nucl. Res. 5, 355 (1979).

17. J. P. Harwood, M. Conti, P. M. Conn, M. L. Dufau and K. J. Catt, Molec, Cell Endocr. 11, 121 (1978),

18. C. Mukherjee, M. G. Caron and R. J. Lefkowitz, Endocrinology 99, 347 (1976).

19. Y. F. Su, L. Cubeddue and J. P. Perkins, J. Cyclic Nucl. Res. 2, 257 (1976).

20. J. P. Harwood, M. L. Dufau and K. J. Catt, Molec. Pharmac, 15, 439 (1979).

21. J. L. Carpentier, P. Gorden, A. Le Cam, P. Freychet and L. Orci, Diabetologia 13, 386 (1977).

22. H. H. Aigler, J. F. Ash, S. J. Singer and S. Cohen, Proc, natn. Acad. Sci. U.S.A. 75, 3317 (1978).

23. F. Van Leuven, J. J. Cassiman and H. Van den Berghe, J. biol. Chem. 254, 5155 (1979).

24. P. J. A. Davies, D. R. Davies, A. Levitzki, F, R. Maxfield, P. Milhaud, M. C. Willingham and I. Pastan, Nature 283, 162 (1980).

25. J. Schlessinger, Y. Schechter, P. Cuatrecasas, M. C. Willinghan and I. Pastan, Proc, natn. Acad. Sci. U,S.A. 75, 5353 (1978).

26. M. A. Lesniak and J. Roth, J. biol. Chem. 251, 3720 (1976). 